\title{
Investigation of emotions management skills, perceived social competence, friendship quality, social exclusion and need to belong in adolescents
}

\author{
Meral Sert Agir ${ }^{1, *}$ \\ ${ }^{1}$ Marmara University, Atatürk Faculty of Education, Department of Educational Sciences, \\ Psychological Counseling and Guidance Department, Göztepe, Istanbul, Turkey
}

\begin{abstract}
The research was conducted to investigate the dynamics between emotional management skills, perceived social competence, friendship quality, social exclusion, and need to belong in adolescents. Previous studies emphasize the importance of competencies in adolescents related to emotional management skills in social and academic life as well as in the family. In this context, emotional management skills gain an importance as a feature that can help adolescents become a member of a group and meet the need to belong by positively changing the perception of the social competence of the individual, increasing social harmony, and developing meaningful and supportive friendships. Research data was obtained by applying "Emotions Management Skills Scale", "Perceived Social Competence Scale", "Friendship Quality Scale", "Social Exclusion Scale", "Need to Belong Scale" and "Personal Information Form" on 431 students (195 male, 236 female) in 9th, 10th, and 11th Grades in Kadıköy district, Istanbul province. Significant differences were found in friendship quality, perceived social competence, and emotions management with respect to gender. In addition, differences were found in investigated characteristics with respect to age, grade, academic achievement, family dynamics and, a negative relationship was found between social exclusion and emotions management skills, perceived social competence, and friendship quality.
\end{abstract}

Keywords: Adolescence Period; Emotions Management Skills; Perceived Social Competence; Social Exclusion; Friendship Quality; Need to Belong

\section{Introduction}

Each period of human development involves many different competences, struggles and opportunities [1]. Among these, adolescence is a critical period in which the neurobiological processes underlying higher cognitive functions and social and emotional behavior matures and change and development take place as individuals overcome many

* Corresponding author: meralagir@marmara.edu.tr-meralagir@yahoo.com 
difficulties in all areas of development [2,3]. Adolescence is the transition period to adulthood, where the individual forms his or her identity through relationships. Definitions of what kind of a person an individual will become are shaped during adolescence [4]. The relationship of adolescents with their family and peers differentiate and prepare them for adulthood as individuals [4]. In this period, the interaction of the individual with his or her family, peers and school environment refer not only to the period of adolescence but also to a process of maturation affecting the whole life [5]. Maturing on the path to become an individual requires independence from childhood to adulthood and being able to assume the responsibilities of being an adult [6]. The adolescence period characterizes the difficulties of the transformation process from the parent-dependent identity structure of childhood to autonomous individuals, and the competences needed to overcome these difficulties and become a healthy adult $[7,8]$. One of the most important emphases of the period is the dynamics of emotional-social development in the context of personality development. The literature on adolescents characterizes this period with rapidly changing emotional states over a short time period [9]. For adolescents, the changing emotional states can be regarded as a sign of development and change to gain emotional competences required throughout life, including the neurophysiological, mental, social, and complex processes of emotion $[10,11]$. In other words, physical changes accompanying emotions give clues about being an "adult" depending on thought and behavior styles, maturation of inherent cognitive and emotional competences, and the process of socialization [12]. Thus, in adolescence, the change and development of emotional behaviors and gaining emotional competence is influential on not only emotions but also development of competences in all developmental areas. Although studies on academic preparations since childhood overshadow emotional and social development, the research shows that emotional-social competences are correlated with school achievement and family-peer interaction quality. Findings indicate that children with emotional and social competences have better school achievement and adaptation and less risk than children having significant emotional and social difficulties $[13,14,15,16]$. The American School Counselors Association also emphasizes the need for a holistic approach of the social-emotional development, academic success and career preparation studies of young people in the information age we live in [17]. In addition, when the content of career preparation/readiness efforts, which have gained more importance in recent years -critical thinking/problem solving, verbal and written communication, leadership, teamwork and collaboration, professional ethics competencies, global-intercultural communication- is taken into account, it is seen that emotion management in terms of social and emotional competences and communication and interaction with other people are effective also in life after adolescence [18,19,20,21]. Thus, the ability of adolescents to be aware of, express, control their emotions and adapt to their own and others' emotions will support the emotional maturation process as an individual and the maturation process in other developmental areas [22]. In this context, emotions management skills can provide a positive change in the perception of the individual's social competence, friendships and membership of a group, especially in their relationships with their peers [23]. These dynamics are even more important when one considers that a person is a social being and creates its identity through others. The skills and competences of social interactions for adolescents who turn towards their peers more than their parents during the process of gaining independence and creating an identity take the function of a mirror to get to know themselves [24,25]. Adolescents form a definition of "social competence" related to their own social skills and performance in relation to their own and others' opinions. Social competence (competence), addressed by some specialists in conjunction with the concept of social skill, is the judgment and verdicts about the assessment of the individual's performance in tasks within the context of social interactions depending on certain criteria given by the individual himself or others -parents, teachers, 
peer groups, etc. [26,27]. Perhaps the most important agent of the judgments and verdicts for adolescents is their peer groups, i.e. friends. Thus, the ability of adolescents to initiate and maintain emotional and social relationships enable them to experience the thought and feeling of "being valuable and liked" as well as belonging - "being accepted" [28,29]. In this context, a young person who is able to perceive him/herself as socially competent experiences the proofs by the status of being accepted by his/her peers, and otherwise becomes excluded or neglected [30,31]. Being a socially accepted non-excluded person enables being perceived as socially competent, which includes characteristics such as emotions management skills, friendship in the context of effective communication skills, trustworthiness, etc. These interacting dynamics can support the healthier development and maturation of an adolescent's identity [33,34].

As can be seen, the level of awareness of the adolescent regarding emotional processes and his/her way of using these is one of the dynamics that influence the perception of social competence and being accepted by peers. In other words, the competency of emotions management skills, together with the need to belong to a group, can affect whether adolescents are excluded by their peers, and their status of being competent/capable individuals. The experiences related to these dynamics leave effects during adolescence, which has a critical importance for identity development, that carry their traces all the way to adulthood.

In this context, this research was conducted to examine adolescents' emotions management skills, perceived social competence, friendship quality, social exclusion, and need to belong.

\subsection{Research Method}

This research was based on the descriptive relational screening model.

\subsection{Study Group}

The study group was selected randomly and consisted of 431 students (195 male, 236 female) from $9^{\text {th }}, 10^{\text {th }}, 11^{\text {th }}$ Grades studying in public high schools in Kadıköy district, Istanbul during 2015-2016 academic year.

\subsection{Data Collection Tools}

For this research, institutional approval was obtained from Istanbul Governorship, Ministry of National Education Issue: 59090411-20-E.4519169 and Date: 21.04.2016. Research data was obtained by using the "Emotions Management Skills Scale" developed by Rezzan Çeçen (internal consistency coefficient of the scale was 0.83 whereas the cronbach alpha value obtained within this research) [35], "Perceived Social Competence Scale" adapted into Turkish by Sarıçam et al. [36], "Friendship Quality Scale" [37], "Social Exclusion Scale" [38], "Need to Belong Scale" [39] adapted into Turkish by Akın et al., and "Personal Information Form" developed by the researcher.

\subsection{Data Analysis}

The data were analyzed in SPSS computer program using t test, one-way analysis of variance and relationship techniques. Differences in social exclusion, need to belong, emotions management skills, perceived social competence and friendship quality with respect to gender were investigated by $t$ test, whereas differences with respect to age, grade, 
student achievement in the current academic year in which the research was carried out and the previous academic year (based on student statement), family characteristics (nuclear, extended, fragmented), number of siblings, parent educational status, parent working status were investigated by one way analysis of variance.

In addition, relationship analysis was performed to determine whether there is a relationship between these characteristics of adolescents.

\section{Results}

Results of this research are listed below.

3.1. There was a significant difference in favor of girls in terms of gender with respect to friendship quality and perceived social competence accordingly. A significant difference in favor of girls was found in the verbal expression sub-dimension of emotions management skills, whereas a significant difference in favor of boys was found in control of negative body response and anger management sub-dimensions.

Table 1. $T$ test results of scales and sub-dimensions according to gender variable

\begin{tabular}{|c|c|c|c|c|}
\hline Scale/Subcale & $\mathrm{t}$ & p & $\begin{array}{c}\bar{x} \\
\text { Male }\end{array}$ & $\begin{array}{c}\bar{x} \\
\text { Female }\end{array}$ \\
\hline Friendship quality & -2.23 & 0.026 & 86.98 & 91.29 \\
\hline Closeness & -3.27 & 0.001 & 25.87 & 28.03 \\
\hline Acceptance & -1.97 & 0.050 & 17.95 & 18.81 \\
\hline Help & -3.42 & 0.001 & 8.38 & 9.29 \\
\hline Social competence & -3.83 & 0.000 & 23.85 & 25.61 \\
\hline Expression of emotions as a verbal & -2.58 & 0.010 & 22.73 & 24.24 \\
\hline Control of negative body response & 5.099 & 0.000 & 13.48 & 11.83 \\
\hline Management of anger & 2.773 & 0.006 & 8.92 & 8.39 \\
\hline
\end{tabular}

3.2. Significant differences were found in terms of social exclusion, friendship quality, security, proximity, acceptance, and assistance scores with respect to the age variable.

Table 2. One-way analysis of variance (Anova) results of scales and sub-dimensions according to age variable

\begin{tabular}{|l|c|c|}
\hline Age & F & p \\
\hline Social exclusion & 3.159 & 0.043 \\
\hline Friendship Quality & 8.410 & 0.000 \\
\hline Safety & 3.823 & 0.023 \\
\hline Closeness & 5.878 & 0.003 \\
\hline Acceptance & 9.403 & 0.000 \\
\hline Help & 10.000 & 0.000 \\
\hline
\end{tabular}

3.3. No significant difference was found in the scales applied and the sub-dimension scores with respect to the grade level of students.

3.4. A significant difference was found in terms of friendship quality, security, assistance, belonging and achievement scores with respect to student achievement in the current academic period. 
Table 3. One-way analysis of variance (Anova) results of scales and sub-dimensions according to student achievement variable

\begin{tabular}{|l|c|c|}
\hline Student Achievement & F & p \\
\hline Friendship Quality & 3.048 & 0.017 \\
\hline Security & 3.118 & 0.015 \\
\hline Help & 3.781 & 0.005 \\
\hline Belonging need & 2.699 & 0.030 \\
\hline Coping & 2.743 & 0.028 \\
\hline
\end{tabular}

3.5. A significant difference was found in terms of social competent scores with respect to academic achievement status in the previous academic period.

Table 4. One-way analysis of variance (Anova) results of scales and sub-dimensions according to previous academic period student achievement variable

\begin{tabular}{|l|c|c|}
\hline Previous Academic Period Student Achievement & F & p \\
\hline Social competence & 2.443 & 0.046 \\
\hline
\end{tabular}

3.6. A significant difference was found in the belonging, emotions management skills, and coping scores within emotions management skills with respect to the number of siblings.

Table 5. One-way analysis of variance (Anova) results of scales and sub-dimensions according to number of siblings variable

\begin{tabular}{|l|c|c|}
\hline Number of Siblings & F & p \\
\hline Belonging need & 3.263 & 0.012 \\
\hline Emotion management skills & 4.073 & 0.003 \\
\hline Coping & 2.931 & 0.021 \\
\hline
\end{tabular}

3.7. A difference was found in terms of emotions management skills with respect to parents being together.

Table 6. One-way analysis of variance (Anova) results of scales and sub-dimensions according to parents living together variable

\begin{tabular}{|l|c|c|}
\hline Parents Living Together & F & p \\
\hline Emotion management skills & 3.176 & 0.043 \\
\hline
\end{tabular}

3.8. A significant difference was found in terms of acceptance, emotions management skills, and verbal expression scores with respect to mother educational status.

Table 7. One-way analysis of variance (Anova) results of scales and sub-dimensions according to mother educational status variable

\begin{tabular}{|l|c|c|}
\hline Mother Educational Status & F & p \\
\hline Acceptance & 2.771 & 0.027 \\
\hline Emotion management skills & 2.929 & 0.021 \\
\hline Expression of emotions as a verbal & 2.961 & 0.020 \\
\hline
\end{tabular}

3.9. Significant difference was found in terms of acceptance, emotions management skills, and verbal expression scores with respect to father educational status.

Table 8. One-way analysis of variance (anova) results of scales and sub-dimensions according to father educational status variable

\begin{tabular}{|l|c|c|}
\hline Father Educational Status & F & p \\
\hline Emotion management skills & 2.754 & 0.028 \\
\hline Expression of emotions as a verbal & 2.456 & 0.045 \\
\hline
\end{tabular}


3.10. According to the results of relationship analysis conducted to determine the relationships between scales, a negative relationship was found between social exclusion and emotions management skills, perceived social competence and friendship quality.

A positive relationship was found between friendship quality and belonging, social competence, and emotions management skills.

A positive relationship was found between belonging and social competence, whereas a negative relationship was found between belonging and emotions management skills.

Table 9. Correlation table between the scales

\begin{tabular}{|c|c|c|c|c|c|c|}
\hline & & $\begin{array}{c}\text { Social } \\
\text { exclusion }\end{array}$ & $\begin{array}{l}\text { Friendshi } \\
\text { p quality }\end{array}$ & $\begin{array}{c}\text { Belonging } \\
\text { need }\end{array}$ & $\begin{array}{c}\text { Social } \\
\text { competences }\end{array}$ & $\begin{array}{c}\text { Emotion } \\
\text { managemen } \\
t \text { skills }\end{array}$ \\
\hline \multirow[t]{3}{*}{$\begin{array}{l}\text { Social } \\
\text { exclusion }\end{array}$} & $\begin{array}{l}\text { Pearson } \\
\text { Corr. }\end{array}$ & 1 & $-.418^{* *}$ & -.031 & $-.437^{* *}$ & $-.397^{* *}$ \\
\hline & $\mathrm{p}$ & & .000 & .522 & .000 & .000 \\
\hline & $\mathrm{N}$ & 431 & 431 & 431 & 431 & 431 \\
\hline \multirow[t]{3}{*}{$\begin{array}{l}\text { Friendship } \\
\text { quality }\end{array}$} & $\begin{array}{l}\text { Pearson } \\
\text { Corr. }\end{array}$ & $-.418^{* *}$ & 1 & $.217^{* *}$ & $.419^{* *}$ & $.213^{* *}$ \\
\hline & $\mathrm{p}$ & .000 & & .000 & .000 & .000 \\
\hline & $\mathrm{N}$ & 431 & 431 & 431 & 431 & 431 \\
\hline \multirow[t]{3}{*}{$\begin{array}{l}\text { Belonging } \\
\text { need }\end{array}$} & $\begin{array}{l}\text { Pearson } \\
\text { Corr. }\end{array}$ & -.031 & $.217^{* *}$ & 1 & $.148^{* *}$ & $-.223^{* *}$ \\
\hline & $\mathrm{p}$ & .522 & .000 & & .002 & .000 \\
\hline & $\mathrm{N}$ & 431 & 431 & 431 & 431 & 431 \\
\hline \multirow[t]{3}{*}{$\begin{array}{l}\text { Social } \\
\text { competences }\end{array}$} & $\begin{array}{l}\text { Pearson } \\
\text { Corr. }\end{array}$ & $-.437^{* *}$ & $.419^{* *}$ & $.148^{* *}$ & 1 & $.279^{* *}$ \\
\hline & $\mathrm{p}$ & .000 & .000 & .002 & & .000 \\
\hline & $\mathrm{N}$ & 431 & 431 & 431 & 431 & 431 \\
\hline \multirow{3}{*}{$\begin{array}{l}\text { Emotion } \\
\text { management } \\
\text { skills }\end{array}$} & $\begin{array}{l}\text { Pearson } \\
\text { Corr. }\end{array}$ & $-.397^{* *}$ & $.213^{* *}$ & $-.223^{* *}$ & $.279^{* *}$ & 1 \\
\hline & $\mathrm{p}$ & .000 & .000 & .000 & .000 & \\
\hline & $\mathrm{N}$ & 431 & 431 & 431 & 431 & 431 \\
\hline
\end{tabular}

\section{Discussion}

According to the gender feature, the average scores of social competences scale perceived as "proximity, help and acceptance" dimensions of friendship quality scale and subscale were found to differ from males in favor of females. It shows that female students find the quality of friendship more positive than male students and find themselves more competent in social relations. This result is consistent with the finding that the mean scores of the "verbal self-expression" dimension from the subscales of emotion management scale differ in favor of female students. In addition, the result that the mean scores of "expression of emotions as they are" and "control of negative body response and anger management" scales differed in favor of male students from emotion management subscales also supported the finding that female students differed in their average level of friendship and perceived social competence. Considering that emotional control and friendship quality are accepted as factors influencing social competence, it is seen that the scores of females are supported by the literature $[40,41,42]$. Similarly, the results regarding other life periods as well as the literature on adolescents have supported emotional management skills and the ability of the individual to find himself or herself socially satisfactory in terms of establishing positive friendships [43]. The mean scores of "control negative body response" and "anger management" dimensions of emotions management skill subscale differ in favor of male students, indicating that male students have more positive qualities than girls in terms of these characteristics. This result makes us think that male students 
may also differ positively in terms of friendship and perceived social competence levels. However, no differences were found in favor of females with respect to qualifications. It is believed that it may be related to the differences in the level of expressing emotions as verbal in male and female students.

Significant differences were found in terms of social exclusion and friendship quality scores with respect to the age of the students. The total scores of friendships quality also differed between the mean scores of security, proximity, acceptance and help subscales. The average scores of the friendship quality scale and the mean scores of the three subdimensions in question differ from the adolescents aged 16 and 17 in favor of the adolescents aged 15. In other words, it is possible to state that quality of friendship relations perceived more positively by adolescents aged 15 than adolescents aged 16 and 17, and their security, proximity and acceptance feelings are more intense in friendships. This result can be supported by the literature that 15-year-old adolescents can maintain their definition of "friendship" in secondary school age and their relationship while their selfdefinition can vary depending on the psychosocial development patterns when they are at the age of 16 and 17 . The stated result can be supported by the finding that the mean scores of the social exclusion scale are at the highest level in the age of 16.

According to the grades of the students, no significant difference was found in terms of the related scale scores. While there was no difference according to the grades, the difference according to the age has suggested that the age factor may be more important in the regulation of the peer relations in terms of related characteristics [44].

In terms of student achievement during the study period, significant differences were found in terms of friendship quality and belonging scores. It was found that the averages of friendship quality scores were higher than those who defined 'very good', 'not bad', 'bad' and 'very bad' in favor of those who defined academic success as good (based on student statement). The fact that students who defined academic achievement as 'very good' had lower average scores of friendship quality $(\bar{x}=80.31)$ than those of other academic achievement categories, suggesting that these students devote less time to social connections due to academic achievement expectations. The average score of the students who see their academic achievement as 'not bad' in terms of the average score of need to belong is higher $(\bar{x}=32.48)$ than the students in the other academic achievement categories. The lowest score average $(\bar{x}=28.42)$ belongs to the students who regard their academic success as 'bad'. This suggests that the need of belonging is more in the students who see themselves in the average. The fact that students evaluating themselves as 'bad' for academic achievement have lower average score of need to belong than students evaluating themselves 'very bad' may be related to the defensive mechanisms that adolescents may have developed about the problems they experience. The fact that the students with perceived academic achievement as 'very bad' $(\bar{x}=30.40)$ and those who perceive as 'very good' ( $\bar{x}=30.66)$ are close to each other can be explained that they are located at both ends of the class average according to the normal distribution curve in both groups $[45,46,47,48]$.

A significant difference was found in terms of social competence scores with respect to academic achievement in the previous semester. Accordingly, the students whose academic achievement is very low $(\bar{x}=20.67)$, have a lower social competence score average than the other academic achievement average scores. Students that perceive themselves average $(\bar{x}=25.48)$ and above average $(\bar{x}=25.20)$ have higher average scores. This situation may be regarded as a social psychological phenomenon, although it appears to be in conflict with the result that average students' need to belong in the previous finding are high. In the light of sociology and social psychology, the middle class in the theory of social stratification can perceive itself more competently than the lower class while experiencing the need to be accepted by the upper class. 
According to the sibling numbers, there was a difference in terms of total score of emotion management skills and sub dimension of coping with. In terms of emotion management skills regarding sibling number, it has been found that children without siblings $(\bar{x}=96.44)$ have higher score of emotion management than children with 2-3 and 4 siblings. Children with 4 siblings $(\bar{x}=85.41)$ have lower scores on emotion management skills than others. The average scores of coping skills of single children was found $(\bar{x}=13.79)$ higher than other groups (the average score of children with 2 or more siblings respectively; $(\bar{x}=12.74 ; \bar{x}=12.95 ; \bar{x}=11.48 ; \bar{x}=12.75)$. It is considered that this result is consistent with preference of having one child or two children increases with the education level according to population growth data of Turkey $[49,50]$. In terms of the literature related to the adolescents, evaluations related to the emotional and social development of the children with siblings are considered together with various factors [51,52,53]. Although it is thought that having a sibling may be more positive than being a single child, this feature requires many familial factors to be dealt with together.

A difference was found in emotion management skills according to the marital state of parents. 384 of the participants in the research reported that their parents live together, 36 have divorced, and 11 reported that their parents live separately. Although the family togetherness is expected to make a difference among young people in terms of dynamics of the study, it is considered that this characteristic should be taken into account with other dynamics related to the family $[54,55]$.

According to the characteristics of maternal education level, there were differences in acceptance sub dimension of friendship quality scale and average total score of emotional management and its sub dimension and sub dimension of expressing verbally. A significant difference was found in terms of friendship quality scores according to maternal education level. Average score of friendship quality of children's mothers who are illiterate $(\bar{x}=78,29)$ or primary school graduate $(\bar{x}=83.77)$ and the total score of emotional management skills of secondary school, high school and university graduates is also considered. Total average score of emotional management skill is lower in those whose mothers are illiterate $(\bar{x}=86.57)$ than mothers graduated from high school $(\bar{x}=94.52)$ or university $(\bar{x}=93.93)$. The psychology literature and a large number of researches emphasize the importance of the individual's qualifications regarding "mother's" characteristics and "motherhood roles and functions" as individuals at every stage of her life. Therefore, the obtained result is consistent with the relevant literature data in terms of maternal education level and friendship quality scale and emotion management skills, and once again emphasizes the importance of this subject [56].

It has also been found that father's education level differs in terms of emotion management skills and expressing verbally in its sub dimensions. It was found that, in terms of average total score of emotion management skills, children having illiterate father $(\bar{x}=87.67)$ differs from primary school graduates $(\bar{x}=90.47)$, secondary school graduates $(\bar{x}=89.26)$, high school graduates $(\bar{x}=92.47)$ and university graduates $(\bar{x}=94.59)$. In the average total score of sub dimensions of expressing the scale verbally in children's father that are illiterate $(\bar{x}=24.67)$ are higher than other groups (respectively $\bar{x}=22.16 ; \bar{x}=22.51$; $\bar{x}=23.76 ; \bar{x}=24.56$ ) The fact that the ones whose father is illiterate and the ones whose father is university graduate are close in terms of total average score of sub dimensions of expressing themselves verbally makes us think that illiterate individuals need more verbal expression to sustain their daily lives. In addition, whether the patterns of expressing verbally are same among educated individuals are evaluated in terms of emotions management skills total score and it has been revealed that it is significant for fathers to be educated as well as mothers.

According to the results of the relationship analysis, a negative relationship was found between social exclusion and emotion management skills, perceived social competence and 
friendship quality. A positive relationship was found between emotion management skills and perceived social competence and friendship quality whereas a negative relationship was found between emotions management skills and social exclusion. The increase in social exclusion informs young people in terms of emotion management skills and perceived social competence that they need support, and their friendship qualities do not have supportive qualifications. In other words, when competence related to emotion management skills increase in young people, communication with their peers, positive perception level of their competences and their friendships quality become supportive and enhancing while social exclusion and neglection by peers decrease. The result obtained supports the relevant literature in terms of research subject $[57,58,59,60]$.

\section{Conclusion and Recommendations}

The results of the study have shown that in the process of acquiring a healthy identity; regulation of emotion management skills and peer relationships, and the importance of selfcompetence perception as well as studies related to the subject should be approached multidimensionally. In this context, it is believed that emotion management skills should be regulated in order to support all its dimensions and social exclusion should be evaluated together with "peer victimization", and incentives of extracurricular activities should be increased to improve friendships. In addition, structuring educational institutions' functions to be comprehensive rather than acquiring "academic qualification" in order to include all individuals, children and the youth can contribute to the healthy development of young individuals. It is suggested that all social institutions and organizations for young people should be in cooperation and coordination for the works supporting young individuals and their families in order to raise awareness for the importance of taking preventive and remedial roles.

\section{References}

1. Bandura, A. Adolescence Development from an Agentic Perspective. Tim Urdan and Frank Pajares (Eds.) Self Efficacy Beliefs of Adolescence (1-47). USA: Information Age Publishing. (2005).

2. Yurgelun, Todd D. Emotional and cognitive changes during adolescence. Current Opinion in Neurobiology, 17(2), 251-257. (2007).

3. McLaughlin, K. A, Megan C. Garrard and Leah H. Somerville. What develops during emotional development? A component process approach to identifying sources of psychopathology risk in adolescence. Dialogues in Clinical Neuroscience, 17(4), 403. (2015).

4. Malatesta, C. Z. The role of emotions in the development and organization of personality. In Nebraska symposium on motivation (Vol. 36, pp. 1-56). (1990, January).

5. Zimmer- Gembeck, M. J. and W. Andrew Collins. Autonomy Development during Adolescence. Gerald R. Adams and Micheal D. Berzonsky (Eds.) Blackwell handbook of adolescence (175-200). UK: Blackwell Publishing. (2006).

6. Zimmerman, B., J. \& Timothy J Cleary. Adolescent's development of personal agency, The role of self- efficacy beliefs and self regulatory skill. Tim Urdan and Frank Pajares (Eds.) Self efficacy beliefs of adolescence (45-69). USA: Information Age Publishing. (2005). 
7. Schunk, Dale H. \& Judith L. Meece. Self-efficacy development in adolesence. Tim Urdan and Frank Pajares (Eds.) Self-Efficacy beliefs of adolescence (71-96). USA: Information Age Publishing. (2005).

8. Dusek, J. B. \& Julie Guay McIntyre. Self-concept and self-esteem development. Gerald R. Adams and Micheal D. Berzonsky (Eds.) Blackwell handbook of adolescence (290-300). UK: Blackwell Publishing. (2006).

9. Crone EA, Dahl RE. Understanding adolescence as a period of social-affective engagement and goal flexibility. Nature Reviews. Neuroscience.13:636-650. (2012).

10. McLaughlin, K. A, Megan C. Garrard and Leah H. Somerville. What develops during emotional development? A component process approach to identifying sources of psychopathology risk in adolescence. Dialogues in Clinical Neuroscience, 17(4), 403410. (2015).

11. Konrad, K., Firk, C., \& Uhlhaas, P. J. Brain development during adolescence: neuroscientific insights into this developmental period. Deutsches Ärzteblatt International, 110 (25), 425. (2013).

12. Susman,E. And Alan Rogal . Puberty and Psychological Development. Richard M. Lerner and Laurence Steinberg (Eds.) Handbook of adolescent psychology (second Edition) (15-45). New Jersey: John Wiley\&Sons, Inc. (2004).

13. Raver, C. C. Young Children's Emotional Development and School Readiness. ERIC Digest. (2003).

14. Nurmi, J-E. Socialization and self-development channeling, selection, adjustment and reflection. Richard M. Lerner and Laurence Steinberg (Eds.) Handbook of adolescent psychologhy (second Edition) (85-124). New Jersey: John Wiley\&Sons, Inc. (2004).

15. Collins, W. A. \&Brett Laurse. Parent-adolescent relationships and influences. Richard M. Lerner and Laurence Steinberg (Eds.) Handbook of adolescent psychologhy (331361), (second Edition). New Jersey: John Wiley\&Sons, Inc. (2004).

16. Brown, B. Adolescents' relationships with peers. Richard M. Lerner and Laurence Steinberg (Eds.) Handbook of adolescent psychologhy (363-394), (second Edition). New Jersey: John Wiley\&Sons, Inc. (2004).

17. American School Counselor Association. ASCA national model: A framework for school counseling programs. American School Counselor Association. (2012).

18. Dymnicki, A., Sambolt, M., \& Kidron, Y. Improving college and career readiness by incorporating social and emotional learning. College and Career Readiness and Success Center. (2013).

19. Kavanagh, M. H., \& Drennan, L. What skills and attributes does an accounting graduate need? Evidence from student perceptions and employer expectations. Accounting \& Finance, 48 (2), 279-300. (2008).

20. Robles, M. M. Executive perceptions of the top 10 soft skills needed in today's workplace. Business Communication Quarterly, 75(4), 453-465. (2012).

21. English, D., Manton, E. J., SAMI, A. R., \& Dubey, A. A comparison of the views of college of business graduate and undergraduate students on qualities needed in the workplace. College Student Journal, 46 (2), 427-435. (2012).

22. Thompson, R. A. Emotional regulation and emotional development. Educational Psychology Review, 3(4), 269-307. (1991).

23. Brown, B. B. and Christia Klute Friendships, cliques and crowds. Gerald R. Adams and Micheal D. Berzonsky (Eds.) Blackwell handbook of adolescence (330-349). UK: Blackwell Publishing. (2006). 
24. Rose, A. J., \& Rudolph, K. D. A review of sex differences in peer relationship processes: potential trade-offs for the emotional and behavioral development of girls and boys. Psychological Bulletin, 132 (1), 98. (2006).

25. Galambos, N. L., \& Costigan, C. L. Emotional and personality development in adolescence. Handbook of Psychology, 351-372. (2003).

26. Connolly, J. Social self-efficacy in adolescence: Relations with self-concept, social adjustment, and mental health. Canadian Journal Of Behavioural Science/Revue Canadienne Des Sciences Du Comportement, 21(3), 258. (1989).

27. Bandura, A., Barbaranelli, C., Caprara, G. V., \& Pastorelli, C. Self-efficacy beliefs as shapers of children's aspirations and career trajectories. Child Development, 72(1), 187-206. (2001).

28. Bacchini, D., \& Magliulo, F. Self-image and perceived self-efficacy during adolescence. Journal of Youth And Adolescence, 32(5), 337-349.(2003).

29. Anderson, S. L., \& Betz, N. E. Sources of social self-efficacy expectations: Their measurement and relation to career development. Journal of Vocational Behaviour, 58(1), 98-117. (2001).

30. Baumeister, R. F., DeWall, C. N., Ciarocco, N. J., \& Twenge, J. M. Social exclusion impairs self-regulation. Journal Of Personality And Social Psychology, 88(4), 589. (2005).

31. Leary, M. R. Responses to social exclusion: Social anxiety, jealousy, loneliness, depression, and low self-esteem. Journal of Social and Clinical Psychology, 9(2), 221-229. (1990).

32. Anderman, L. H.). Academic and social perceptions as predictors of change in middle school students' sense of school belonging. The Journal of Experimental Education, 72(1), 5-22. (2003

33. Wilkinson, R. G., \& Marmot, M. (Eds.). Social determinants of health: the solid facts. World Health Organization. (2003).

34. Derfler-Rozin, R., Pillutla, M., \& Thau, S. Social reconnection revisited: The effects of social exclusion risk on reciprocity, trust, and general risk-taking. Organizational Behavior and Human Decision Processes, 112(2), 140-150. (2010).

35. Çeçen, A. R. Duyguları yönetme becerileri ölçeğinin geliştirilmesi: Geçerlik ve güvenirlik çalışmaları. Türk Psikolojik Danışma ve Rehberlik Dergisi, 3(26), 101-113. (2006).

36. Sarıçam, H., Akın, A., Akın, Ü., \& Çardak, M. Algılanan Sosyal Yetkinlik Ölçeğinin Türkçeye uyarlanması: Geçerlik ve güvenirlik çalışması. The Journal of Academic Social Science Studies, 6(3), 591-600. (2013).

37. Akın, A., Karduz Adam, F. F., \& Akın, Ü. Arkadaşlık kalitesi ölçeği Türkçe formunun geçerlik ve güvenirliği. Journal of Research in Education and Teaching, 3(4), 378383. (2014).

38. Akın, A., Doğan, R., Gönülalan, G. D., Atik, R., Çebiş, T., Akın, U. Ergenler için sosyal dişlanma ölçeği Türkçe formunun geçerlik ve güvenirliği. Paper presented at the $1^{\text {st }}$ Eurasian Educational Research Congress, April, 24-26, İstanbul, Türkiye. (2014).

39. Akın, A. Ait Olma ihtiyacı ölçeği. Ahmet Akın. (Eds.) Psikolojide kullanılan güncel ölçme araçları . İstanbul: Nobel. (2015). 
40. Silvers, J. A., McRae, K., Gabrieli, J. D., Gross, J. J., Remy, K. A., Ochsner, K. N. Age-related differences in emotional reactivity, regulation, and rejection sensitivity in adolescence. Emotion, 12(6), 1235. (2012).

41. Carlo, G., Crockett, L. J., Wolff, J. M., \& Beal, S. J. The role of emotional reactivity, self-regulation, and puberty in adolescents' prosocial behaviors. Social Development, 21(4), 667-685. (2012).

42. Myin-Germeys, I., Van Os, J., Schwartz, J. E., Stone, A. A., \& Delespaul, P. A. Emotional reactivity to daily life stress in psychosis. Archives of General Psychiatry, 58(12), 1137-1144. (2001).

43. Li, Y., Doyle Lynch, A., Kalvin, C., Liu, J., \& Lerner, R. M. Peer relationships as a context for the development of school engagement during early adolescence. International Journal of Behavioural Development, 35(4), 329-342. (2011).

44. Birditt, K. S., Fingerman, K. L., \& Almeida, D. M. Age differences in exposure and reactions to interpersonal tensions: a daily diary study. Psychology and Aging, 20(2), 330. (2005).

45. Pajares, F.. Self-efficacy beliefs in academic settings. Review of Educational Research, 66(4), 543-578. (1996)

46. Pajares, F., \&Schunk, D. The development of academic self-efficacy. Development of Achievement Motivation. United States, 7. (2001).

47. Bong, M., \& Skaalvik, E. M. Academic self-concept and self-efficacy: How different are they really?. Educational Psychology Review, 15(1), 1-40. (2003).

48. Pintrich, P. R., \& Zusho, A. The development of academic self-regulation: The role of cognitive and motivational factors. In A. Wigfield \& J. S. Eccles (Eds.), A Vol. in the educational psychology series. Development of achievement motivation (pp. 249-284). San Diego, CA, US: Academic Press. (2002).

http://dx.doi.org/10.1016/B978-012750053-9/50012-7

49. ÇobanN, A. İ., \& Özbesler, C. Türkiye'de aileye yönelik sosyal politika ve hizmetler. Sosyal Politika Çalı̧̧maları Dergisi, 18(18), 31-41. (2009).

50. Akça, H., \& Ela, M. Türkiye'de eğitim, doğurganlık ve işsizlik ilişkisinin analizi. Maliye Dergisi, 163, 223-242. (2012).

51. Katz, L. F., Kramer, L., \& Gottman, J. M. Conflict and emotions in marital, sibling, and peer relationships. Conflict in Child and Adolescent Development, 122-149. (1992).

52. Brody, G. H. Sibling relationship quality: Its causes and consequences. Annual Review of Psychology, 49(1), 1-24. (1998).

53. Brody, G. H. Siblings' direct and indirect contributions to child development. Current Directions in Psychological Science, 13(3), 124-126. (2004).

54. Morris, A. S., Silk, J. S., Steinberg, L., Myers, S. S., \& Robinson, L. R. The role of the family context in the development of emotion regulation. Social Development, 16(2), 361-388. (2007).

55. Buehler, C., \& Welsh, D. P. A process model of adolescents' triangulation into parents' marital conflict: The role of emotional reactivity. Journal of Family Psychology, 23(2), 167. (2009).

56. Fox, N. A., \& Calkins, S. D. The development of self-control of emotion: Intrinsic and extrinsic influences. Motivation and Emotion, 27(1), 7-26. (2003).

57. Connolly, J. Social self-efficacy in adolescence: Relations with self-concept, social adjustment, and mental health. Canadian Journal of Behavioural Science/Revue Canadienne des Sciences du Comportement, 21(3), 258. (1989). 
58. Twenge, J. M., Baumeister, R. F., DeWall, C. N., Ciarocco, N. J., \& Bartels, J. M. Social exclusion decreases prosocial behavior. Journal of Personality and Social Psychology, 92(1), 56. (2007).

59. Carthy, T., Horesh, N., Apter, A., \& Gross, J. J. Patterns of emotional reactivity and regulation in children with anxiety disorders. Journal of Psychopathology and Behavioral Assessment, 32(1), 23-36. (2010).

60. Urdan, T., \& Schoenfelder, E. Classroom effects on student motivation: Goal structures, social relationships, and competence beliefs. Journal of School Psychology, 44(5), 331-349. (2006). 